\title{
The record of the Quaternary on continental shelves - their interpretation, correlation and applications
}

\author{
Department of Earth Sciences, The University of Hong Kong, Pokfulam Road, Hong Kong SAR, China
}

Continental shelves provide a direct record of Quaternary sea-level changes but have not played a major role in land-sea correlation. This is attributed mainly to the lack of a major international initiative like the Ocean Drilling Programme on shelves, the high cost of offshore drilling, and, the restrictions imposed on the release of information obtained by the offshore petroleum industry. The main aim of International Geological Correlation Programme project number 396 (IGCP 396) initiated in 1996 is to study and interpret Quaternary sequences on shelves to permit global correlation of sea-level and climatic changes while at the same time identify beneficial uses for humankind. This paper provides information on the project including selected highlights from the research conducted to date.

\section{Introduction}

Continental shelves can be defined as continental margins between the present day shoreline down to a water depth of about $200 \mathrm{~m}$. They are a finite non-renewable resource of great importance to humankind as they make a significant contribution to the world's food and mineral production. They are also areas where new land is created through coastal land reclamation to satisfy the land shortage problem in many parts of the world notably the Netherlands and Japan. Consequently, a better understanding of shelves during the Quaternary is needed for their sustainable utilization and management.

Although shelves provide a direct geological record of Quaternary sea-level changes, they have not played a major role in land-sea correlation. In comparison to deep-sea sediment research, the investigation of shelf sediments and the evidence of Quaternary sea-level change they provide have received little attention. This is attributed mainly to the lack of a major international initiative like the Ocean Drilling Programme, the high cost of offshore drilling, and, the restrictions imposed on the release of information obtained by the offshore petroleum industry. The IGCP 396 is a 5-year project funded by UNESCO/IUGS initiated in 1996 that is aimed specifically at filling this gap in our knowledge. The aim of this paper is to provide information on the project including selected highlights from the research conducted to date.

\section{Project goals}

The main objectives of IGCP 396 are to study and interpret the Quaternary sequences on continental shelves to permit global correlation of sea-level and climatic changes while at the same time identify beneficial uses for humankind. Major topics studied include:

1. Drilling methods.

2. Shelf processes.

3. Sea-level and climatic changes.

4. Marine flora and fauna including corals, molluscs and microfossils.

5. Terrestrial flora and fauna including migration routes.

6. Soil development during low sea-level stands.

7. Continental palaeo-hydrology particularly during glacial periods.

8. Correlation with the deep-sea sedimentary record.

9. Correlation with the continental sedimentary record.

10. Engineering properties of shelf sediments.

11. Comparison of results obtained from a wide range of Quaternary dating methods.

12. Contribution to the global carbon cycle.

13. Living and non-living resources.

14. Use of continental shelves for waste disposal.

In order to achieve the goals of the project, seven working groups have been set up:

1. Dating - Leader Allan Chivas (Fax: 61-42-214250; E-mail: a.chivas@uow.edu.au).

2. Sequence stratigraphy - Leader Francesco Chiocci (Fax: 39-644585080; E-mail: chiocci@geo.geo.uniroma1.it).

3. Siliciclastics - Leader Yoshiki Saito (Fax: 81-298-543533; Email: yoshi@gsj.go.jp).

4. Carbonates - Leader Peter Davies (Fax: 61-2-93510184; E-mail: pjd@es.su.oz.au).

5. Palaeo-oceanography - Leader Bill Austin (Fax: 44-1334463849; E-mail: wena@st-andrews.ac.uk).

6. Marine processes and marine geotechnics - Leader Wyss Yim (Fax: 852-25176912; E-mail: wwsyim@hku.hk)

7.Living and non-living resources - Leader Heiner Josenhans (Fax: 1-902-4264104; E-mail: josenhan@agc.bio.ns.ca).

IGCP 396 holds one conference annually which is aimed mainly at the promotion of scientific exchanges between participants. The 1996, 1997, 1998 and 1999 annual conferences were held in Sydney Australia, Durham United Kingdom, Goa India, and, Cape Town South Africa respectively. In 2000, the final annual conference will be held in conjunction with the 31 st International Geological Congress in Rio de Janeiro from 6-17th August (http://www.31igc.org). News and information on the project are posted on http://www2.env.uea.ac.uk/gmmc/. 


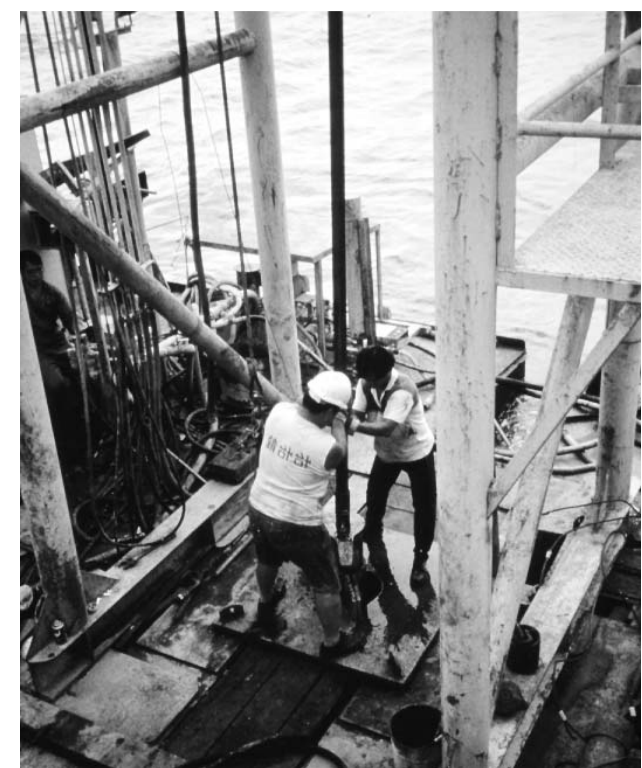

Figure 1 The wire-line vibrocoring technique used for drilling the inner shelf of the South China Sea off Hong Kong.

\section{Selected highlights from the research conducted to date}

Drills needed for obtaining long continuous Quaternary sequences on shelve s are being improved. In Hong Kong where the seabed depth rarely exceeds about $50 \mathrm{~m}$, the wire-line vibrocoring technique operating from barges (Figure 1) was particularly successful for recovering cohesive sediments (Yim, 1999a). By inserting screw-on 6-m casings into the seabed, cores exceeding 6-m in length can be obtained. An important advantage of the cores obtained over those collected by rotary drilling is that the former is less prone to contamination in magnetic susceptibility studies. The University of Sydney and the Australian Geological Survey Organization are currently developing the portable remotely operated drill (PROD) (Figure 2). This drill is designed for $100-\mathrm{m}$ sub-surface penetration and water depths down to $2,000 \mathrm{~m}$.

The widespread occurrence of relic sediments on many shelves of the world was first demonstrated by Emery (1968). This does not fit in well with the high sedimentation rates indicated by oxygen-isotope stratigraphy of deep-sea cores. A better understanding is needed on both the processes of sediment delivery from continents to oceans and the reliability of radiocarbon dates obtained from foraminiferal fractions of deep-sea cores. These issues are highlighted by two recent studies on shelves. During the Holocene, the Kaoping Submarine Canyon was demonstrated by Liu and Liu (1999) to have a negligible role in the transport of terrigenous sediments into the deeper parts of the South China Sea. Based on the radiocarbon dating of samples with good stratigraphic control on the Hong Kong shelf, uncorrected dates exceeding about $8.2 \mathrm{ka}$ are found to show a young age bias (Yim, 1999b).

During glacial period(s), shelves were subjected to desiccation (Yim and Tovey, 1995). The siliciclastics-dominated Hong Kong shelf was affected by acid-sulphate soil development to form up to four palaeo-desiccated crusts on the upper part of stages 5, 7, 9 and 11 deposits. A photomicrograph showing part of a palaeo-desiccated crust developed in stage 5 deposits is shown in Figure 3. Because pyrite formed authigenically in marine sediments were oxidized to maghemite, magnetic susceptibility is a useful tool for the identification of such crusts (Figures 4 and 5). Additionally, Holocene marine sediments are characterized by a honeycomb fabric (Tovey and Yim, 1996) and display distinctive engineering properties such as a higher moisture content than their pre-Holocene counterparts (Choy, 1997). Consequently, the Holocene/Pleistocene boundary can be dated with a greater degree of certainty on shelves in comparison to terrestrial and deep-sea environments (Yim, 1997).

Seismic reflection profiles and borehole data have allowed the British Geological Survey to examine the distribution, thickness and evolution of late Pliocene and Quaternary sediments on the continental shelf of the United Kingdom and to tentatively propose regionally correlative stratigraphic framework (Holmes, 1997). In the North Sea Basin, the thickness of the Quaternary typically exceeds $400 \mathrm{~m}$ with the sedimentation rate either greater than or equal to basin subsidence.

New methods are available for dating shelf sequences. For example, single grain ${ }^{40} \mathrm{Ar}-{ }^{39} \mathrm{Ar}$ ages of glauconies can be obtained (Smith et al., 1998).

The uplifted Pleistocene shelf sequences in the Wanganui Basin, New Zealand show a long Quaternary sequence of transgressive system tracts. A total of 58 sea-level cycles was recognized by Naish et al. (1998). In the sequence stratigraphic model, highstand system tracts, mid-cycle condensed shellbeds, and, transgressive system tracts were recognized by Abbott (1997).

The marine geological record from the Barents and Kara Sea Shelf in the Eurasian Arctic shows that grounded ice sheets largely controlled Quaternary erosion and deposition on this vast continental shelf (Polyak, 1999). Based on seismic records and boreholes, the Quaternary sedimentary sequence are dominated by the presence of three units comprised of glacial sediments, glacial-marine sediments and marine sediments resting unconformably on Mesozoic bedrock.

Shelves provide information on the palaeo-drainage during low sea-level stands. In the eastern Atlantic shelf off the coast of France, evidence for palaeo-drainage networks of the Gironde River and the English Channel River down to water depth of $70 \mathrm{~m}$ was found (Lericolais, 1998). In the Black Sea Shelf, high resolution seismic and Chirp data revealed a large incision $800 \mathrm{~m}$ in depth and $1.5 \mathrm{~km}$ in width (Lericolais et al., 1999). There is therefore a connection between the scale of continental glaciation and the development of palaeo-drainage on shelves during glacial periods.

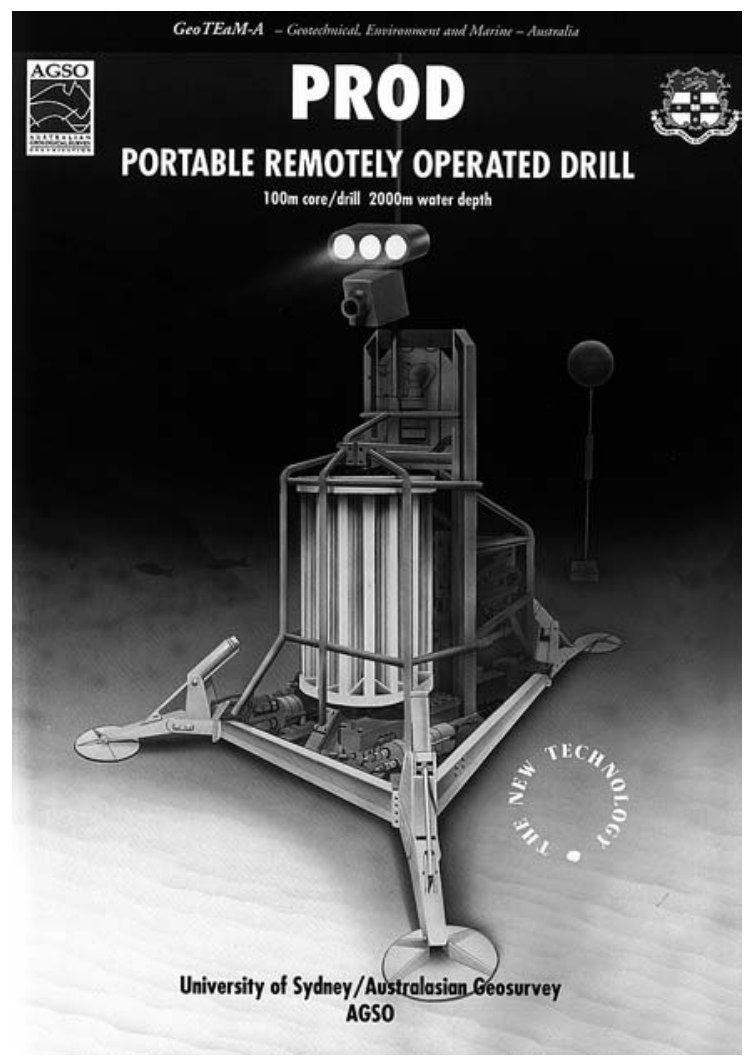

Figure 2 The portable remotely operated drill (PROD) currently being developed by the University of Sydney and the Australian Geological Survey Organization. 


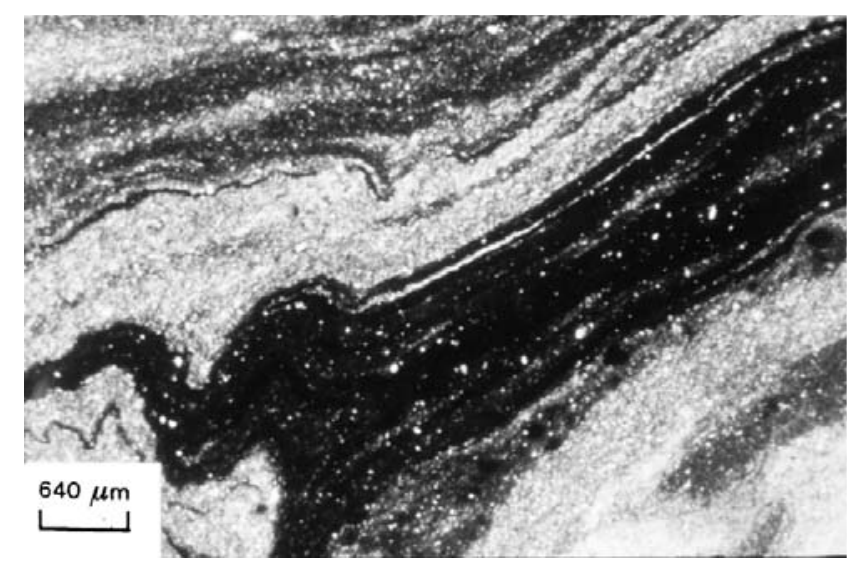

Figure 3 Photomicrograph of part of a palaeo-desiccated crust developed in stage 5 marine deposits during the last glacial maximum (stage 2). The sample is from a borehole located at the New Hong Kong International Airport site.

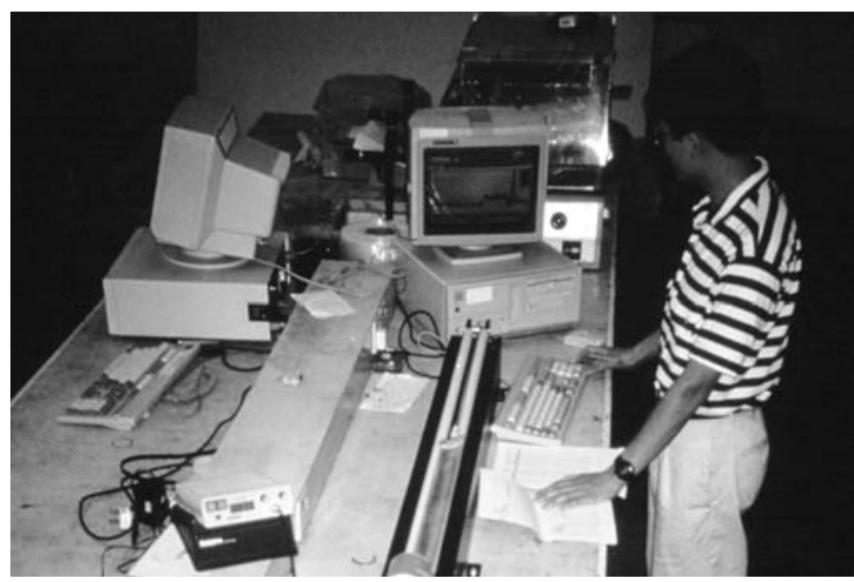

Figure 4 Measurement of magnetic susceptibility of cores using the Bartington MS2 system. This technique has been found to provide valuable stratigraphic information through the identification of palaeo-desiccated crusts in siliciclasticsdominated shelves.

In the Great Barrier Reef of Australia, drilling indicated that reef development dated back only to the Middle Pleistocene (Davies et al., 1996). A 210-m long core drilled through the reef flat at Ribbon Reef 5 revealed 8-reef sequences separated by diagenetic boundaries (Webster and Davies, 1996). Although conclusions are preliminary at present, sea-level oscillation and temperature change appear to be responsible.

The contribution of shelves to the global carbon cycle is a subject of paramount importance. IGCP 396 is working on this topic with IGCP 404 'Terrestrial carbon in the last $125 \mathrm{ka}$. Early results indicate the release of fossil methane from shelves is of considerable importance and should be taken into account in the global carbon budget (Yim, 1999c). In order to quantify this, areas of acoustic turbidity detected on high-resolution boomer seismic profiles can be mapped for determining the proportion of the present day shelves affected.

Based on sediment traps set up on the shelf off Sydney in Australia, sewage-derived organic carbon was found to form a small portion of the organic carbon load to shelf sediments (Bickford, 1996). The data indicated that there is a large variability in sedimentation rates of organic carbon between quiescent periods and large storm events. In order to gain a better understanding of the relative importance of sediments in the nutrient cycle of shelf waters, it is necessary to study the nutrient regeneration processes in shelf sediments (Koop, 1996).
Shelves contain information on the migration of early humans. Dramatic and locally variable changes in post-glacial sea-level history was obtained by seismic reflection surveys and radiocarbon dating of core samples from the continental shelf off British Columbia in Canada (Josenhans et al., 1997). The lowering of sea level to 153 $\mathrm{m}$ provided easily negotiated coastal migration routes for early humans. This is supported by the discovery of stone tools from raised marine deposits with attached barnacles dated at $9.2 \mathrm{ka}$.

Seasonal-scale records can be obtained through the study of sequences in inlets. A 133-year sedimentary sequence in the Saanich Inlet of British Columbia was identified by Collins (1997) to offer insights into climatic controls during the years 1860-1993 AD.

Scuba observations down to a maximum seabed depth of $60 \mathrm{~m}$ below present day sea level permitted the identification of eustatic erosional levels in the Mediterranean Sea and the Caribbean Sea (Collina-Girard, 1999). Mapping in Provence, Corsica; Elba Island, and, Marine-Galante in the West Indies has revealed sea-level stillstands at $-11 \mathrm{~m},-17 \mathrm{~m},-25 \mathrm{~m},-35 \mathrm{~m},-45 \mathrm{~m}$, and $-50 \mathrm{~m} / 55 \mathrm{~m}$. Tectonic or isostatic movements accounted for up to $5 \mathrm{~m}$ difference between the four localities.

The Gulf of Carpentaria in northern Australia is an epicontinental sea with a maximum depth of $70 \mathrm{~m}$ in the present day. Throughout the Quaternary, during times of low sea level and some interstadials, the Gulf was separated giving rise to Lake Carpentaria (Chivas et al., 1999). Cores collected to a maximum depth of $14.9 \mathrm{~m}$ show the presence of lacustrine sediments reflecting both freshwater and highly saline conditions.

A continental scale view of sedimentation patterns is possible through digital database/GIS of shelves. The AUSEABED project of Australian shelf (Jenkins, 1996) is an example.

In 'stable' shelves such as off Hong Kong, the occurrence of five interglacial cycles dating back to the Middle Pleistocene (oxygenisotope stage 12) have been recognized. This is in agreement with the five glacial-interglacial cycles found in the Vostok ice core by Petit et al. (1997). Since the late Quaternary record (oxygen-isotope stage 5 to present) on many shelves are indicative of appreciably lower sedimentation rates than those obtained through the study of deep-sea cores, it is important to resolve these differences in landsea correlation.

High-resolution records of palaeo-environmental change on shelves are available through the study of coral skeletons. Tracers include oxygen isotopes, $\mathrm{Sr}-\mathrm{Ca}$ palaeo-thermometry, trace elements, stable carbon isotopes, radiocarbon, growth banding and fluorescence. Based on $\mathrm{Sr} / \mathrm{Ca}$ and ${ }^{18} \mathrm{O} /{ }^{16} \mathrm{O}$ ratios in corals, information on temperature and surface-ocean water balance of the mid-Holocene were obtained by Gagan et al. (1998). Similar studies on uplifted coral reef terraces such as Sumba in Indonesia (Pirazzoli et al., 1993) and other localities should therefore provide windows for examining palaeo-environmental change during the pre-Holocene interglacial periods.

Sediments and corals in combination are effective in providing information on shelf dynamics. A warm-water platform and coolwater shelf carbonates facies transition was recognized in the Abrolhos Shelf of southwestern Australia (Collins et al., 1997). A poleward-flowing warm water current (the Leeuwin Current) exerted influence on the biotic transition and the relatively high southerly latitude of the Abrolhos reef platforms, which are near the temperature limits of reef-building coral growth. This was attributed to regional patterns of oceanographic circulation, driven in the long term by changes in palaeo-latitude.

The existence of palaeo-desiccated crusts on shelves is a hazard to jack-up platforms used in the offshore petroleum industry (Castleberry II and Prebaharan, 1985). This is demonstrated by two gas production platforms on the northwest shelf of Australia. Remedial work on North Rankin A and Goodwyn A was required costing in excess of AUS $\$ 300$ million each. The foundation problems that existed were related to the occurrence of hard cemented calcareous sands on the shelf (Carter, 1996).

The knowledge gained on shelf sequences is important for coastal regions undertaking major land reclamation. Two examples 


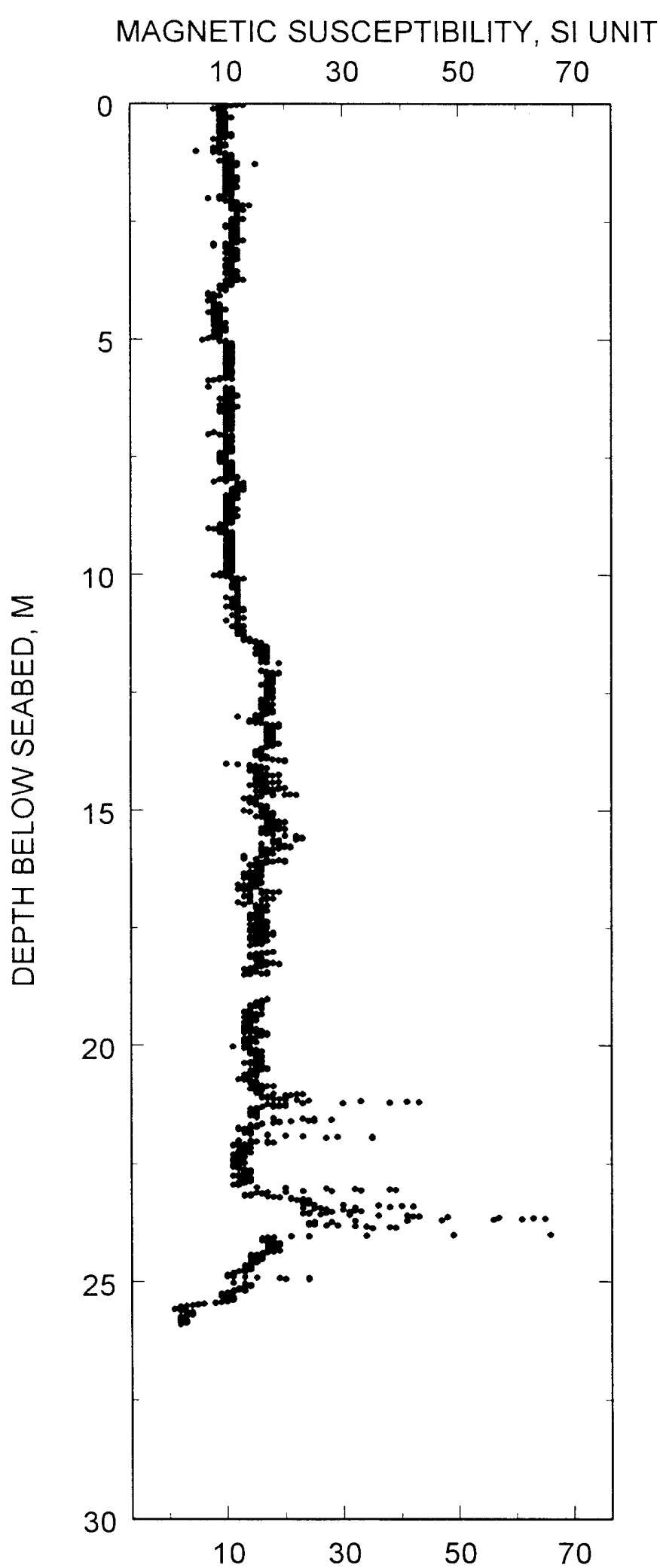

Figure 5 Magnetic susceptibility profile of a continuous 26-m vibrocore from Hong Kong showing the presence of stages 1, 5 and 7 deposits. Increase in magnetic susceptibility can be seen in the upper part of the stage 1 where the sediment is contaminated mainly by shipping activities, at the junction between stages 1 and 5 , and at the junction between stages 5 and 7. The latter two indicates the formation of palaeo-desiccated crusts during stages 2 and 6 respectively.

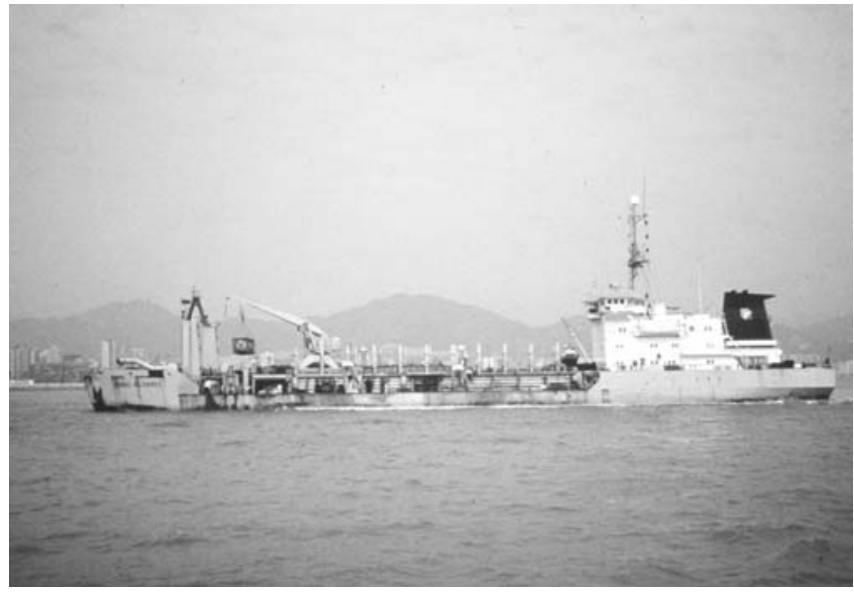

Figure 6 A trailing hopper suction dredger used for the dredging of offshore sand and gravel deposits in Hong Kong.

are the Kansai International Airport in Japan and the New Hong Kong International Airport in China. The former was constructed on an artificial island reclaimed from an area with an average water depth of $18 \mathrm{~m}$ in Osaka Bay. This airport costs US $\$ 15$ billion or over 50 per cent above the estimated budget due mainly to unforeseen settlement problems in the unconsolidated deposits. The latter was constructed in an inshore area with an average water depth of $4 \mathrm{~m}$ adjacent to the mouth of the Pearl River Estuary. In the design and construction of this airport, sequence stratigraphy was taken into account in that the soft easily dredged Holocene marine sediments were removed prior to reclamation. Because of the difficulty in dredging the over-consolidated last interglacial marine deposits, they have been left largely in tact and necessitate the use of various in situ consolidation methods including dynamic compaction.

The inner shelf of the South China Sea off Hong Kong has produced an estimated 300 million $\mathrm{m}^{3}$ of sand and gravel aggregates from a depth of between 25-50 m below the present sea level (Yim, 1999d). Based on the sequence stratigraphy, the bulk of the deposits were formed either during stage 6 or an earlier period. During the peak period of coastal land reclamation activity in 1993, about threequarters of the world's dredging fleet were involved in the former colony. A trailing hopper suction dredger used for dredging offshore sand and gravel deposits in Hong Kong is shown in Figure 6.

Offshore exploration and exploitation of diamonds on the shelf of western South Africa revealed that the diamonds are associated with deposits with a highly complex origin (Shaw, 1998). These deposits were formed through the interaction of high-energy fluvial, aeolian and marine processes operating since Late Cretaceous times. Diamonds are associated with lag deposits on the mid-shelf and appeared to be preferentially entrapped in areas of increased bedrock roughness. The data interpretation was assisted by high-resolution seismic and direct observations of the seabed using the Jago submersible.

Seabed morphology and seabed composition are found to influence fisheries habitats (Josenhans, 1997). Methods including swath mapping, high-resolution side-scan sonar, bottom sediment sampling and submersible observations were applicable on the Scotian Shelf off eastern Canada to provide a better understanding on these habitats.

\section{Future work}

For studying Quaternary sequences on shelves, there is a demand for a low-cost drilling system effective in both cohesive and non-cohesive sediments for collecting 'long' continuous cores. Although drilling technology for the inner shelf is already well established, long cores in many parts of the world are made only for major 
coastal engineering projects because they are costly. Shelf researchers should therefore make an effort to work on the cores provided by these projects. An important focus for future work is the use of the shelf sequences established for land-sea correlation as a test of their validity.

IGCP 396 is a highly ambitious project covering a wide spectrum of topics of great societal relevance. The project should therefore be seen only as a starting point of an international collaborative effort to improve our understanding of shelves in the Quaternary. More funding for research work is needed at the national, regional and international levels.

\section{Acknowledgements}

IGCP 396 receives seed funding from UNESCO and the International Union of Geological Sciences. I would like to thank the participants from the thirty-eight countries for their support and their scientific contributions.

\section{References}

Abbott, S.T. 1997. Mid-cycle condensed shellbeds from mid-Pleistocene cyclothems, New Zealand: implications for sequence architecture: Sedimentology, v. 44, pp. 805-824.

Bickford, G.P. 1996. Organic carbon sedimentation rates in mid-shelf sediments: Abstracts IGCP 396 Inaugural Meeting, Sydney, pp. 7-9.

Carter, J. 1996. Some major geotechnical problems associated with Australia's offshore oil and gas production: Abstracts IGCP 396 Inaugural Meeting, Sydney, pp. 13.

Castleberry II, J.P. and Prebaharan, N. 1985. Clay crusts of the Sunda Shelf - a hazard to jack-up platforms: Proceedings 8th Southeast Asian Geotechnical Conference, Kuala Lumpur, pp. 40-48.

Chivas, A.R., Garcia, A., Holt, S., Reeves, J., Couapel, M., Pearson, G., Edgar, T. and De Deckker, P. 1999. The late Quaternary history of the epicontinental shelf and lake in the Gulf of Carpentaria: Abstracts IGCP 396 4th Annual Conference, Cape Town, pp. 13.

Choy, A.M.S.F. 1997. Quaternary environmental changes and engineering properties of inner shelf sediments from Hong Kong: Abstracts IGCP 396 2nd Annual Meeting, Durham, pp. 5.

Collina-Girard, J. 1999. Scuba observations of stillstand levels in Provence, Corsica, Italia (Elba Island) and in West Indies (Marine-Galante): a worldwide sequence: Abstracts IGCP 396 4th Annual Conference, Cape Town, pp. 15.

Collins, A.D. 1997. Interannual variability of laminated sediment and its relationship to climate in Saanich Inlet, British Columbia: Abstracts IGCP 396 2nd Annual Meeting, Durham, pp. 6.

Collins, L.B., France, R.E., Zhu, Z.R. and Wyrwoll, K.-H. 1997. Warmwater platform and cool-water shelf carbonates of the Abrolhos Shelf, southwest Australia, in James, N.P. and Clarke, J., eds., Cool-Water Carbonates: SEPM Special Publication 56, pp. 23-36.

Davies, P.J., Braga, J.C., Elderfield, E., Kay, L., Kroon, D., McKenzie, J. and Montaggioni, L. 1996. Preliminary results regarding the origin and evolution of the Great Barrier Reef: Abstracts IGCP 396 Inaugural Meeting, Sydney, pp. 26-27.

Emery, K.O. 1968. Relict sediments on continental shelves of the world: Bulletin American Association Petroleum Geologists, v. 52, pp. 445-464.

Gagan, M.K., Ayliffe, L.K., Hopley, D., Cali, J.A., Mortimer, G.E., Chappell, J., McCulloch, M.T. and Head, M.J. 1998. Temperature and surfaceocean water balance of the mid-Holocene tropical western Pacific: Science, v. 279, pp. 1014-1015.

Holmes, R. 1997. Quaternary correlation around the United Kingdom continental shelf: Abstracts IGCP 396 2nd Annual Meeting, Durham, pp. 17.

Jenkins, C.J. 1996. Digital database delineation of Australian shelf sediment facies: Abstracts IGCP 396 Inaugural Meeting, Sydney, pp. 57.

Josenhans, H.W. 1997. The influence of seabed morphology and seabed composition on fisheries habitat: Abstracts IGCP 2nd Annual Meeting, Durham, pp. 19-20.

Josenhans, H., Fedje, D., Piemitz, R. and Southon, J. (1997). Early humans and rapidly changing Holocene sea-levels in the Queen Charlotte Islands - Hecate Strait, British Columbia, Canada: Science, v. 277, pp. 71-74.

Koop, K. 1996. Biogeochemical processes in coastal marine sediments off Sydney. Abstracts IGCP 396 Inaugural Meeting, Sydney, pp. 16-20.
Lericolais, G. 1998. Disappearance of the Gironde River and English Channel River incisions beyond isobath $70 \mathrm{~m}$ off western France: Abstracts IGCP 396 3rd Annual Conference, Goa, pp. 8.

Lericolais, G., Panin, N., Ryan, W., Guichard, F., Berne, S., Ion, G. and the BLASON scientific crew 1999. Preliminary results of the Blason survey: Quaternary sea-level fluctuations in the Black Sea: Abstracts IGCP 396 4th Annual Conference, Cape Town, pp. 24.

Liu, J.T. and Liu, K.-J. 1999. The effect of a submarine canyon on the inner shelf sediment movements: conduit and barrier: Abstracts IGCP 4th Annual Conference, Cape Town, pp. 25.

Naish, T.R., Abbott, S.T., Alloway, B.V., Beu, A.G., Carter, R.M., Edwards, A.R., Journeaux, T.D., Kamp, P.J.J., Pillans, B.J., Saul, G. and Woolfe, K.J. 1998. Astronomical calibration of a southern hemisphere Plio-Pleistocene reference section, Wanganui Basin, New Zealand: Quaternary Science Reviews, v. 17, pp. 695-710.

Petit, J.R., Basile, I., Leruyuet, A., Raynaud, D., Lorius, C., Jouzel, J., Stievenard, M., Lipenkov, Barkov, N.I., Kudryashov, B.B., Davis, M., Saltzman, E. and Kotlyakov, V. 1997. Four climatic cycles in Vostok ice core. Nature, v. 387, pp. 359.

Pirazzoli, P.A., Radtke, U., Hantoro, W.S., Houannic, C., Hoang, C.T., Causse, C. and Borel Best, M. 1993. A one million-year-long sequence of marine terraces on Sumba Island, Indonesia: Marine Geology, v. 109, pp. 221-236.

Polyak, L. 1999. Glacial controls on the Quaternary evolution of the Barents and Kara Sea Shelf, Eurasian Arctic: Abstracts IGCP 396 4th Annual Conference, Cape Town, pp. 33.

Shaw, M.J. 1998. Diamonds on the continental shelf of western Southern Africa. Abstracts IGCP 396 3rd Annual Conference, Goa, pp. 60.

Smith, P.E., Evensen, N.M., York, D. and Odin, G.S. 1998. Single grain ${ }^{40} \mathrm{Ar}-{ }^{39} \mathrm{Ar}$ ages of glauconies: implications for the geologic time scale and global sea-level variations: Science, v. 279, pp. 1517-1519.

Tovey, N.K. and Yim, W.W.-S. 1996. Desiccation of Quaternary shelf sediments: microfabric observations: Abstracts IGCP 396 Inaugural Meeting, Sydney, pp. 96.

Webster, J.M. and Davies, P.J. 1996. Coral variation and its palaeoenvironmental significance in the Ribbon Reef 5 core in the northern Great Barrier Reef: Abstracts IGCP 396 Inaugural Meeting, Sydney, pp. 104.

Yim, W.W.-S. 1997. Pedogenesis as a stratigraphic marker in siliciclastic shelves: Abstracts IGCP 396 2nd Annual Meeting, Durham, pp. 41.

Yim, W.W.-S. 1999a. The wire-line vibrocoring technique used for coring inner shelf Quaternary sequences off Hong Kong, China: Abstracts IGCP 396 4th Annual Conference, Cape Town, pp. 44.

Yim, W.W.-S. 1999b. Radiocarbon dating and the reconstruction of late Quaternary sea-level changes in Hong Kong: Quaternary International, v. 55, pp. 77-91.

Yim, W.W.-S. 1999c. The contribution of carbon in a 'stable' siliciclasticsdominated inner continental shelf: Abstracts 15th INQUA Congress, Durban, pp. 200-201.

Yim, W.W.-S. 1999d. Sequence stratigraphy and dating of sand and gravel deposits from the inner shelf of the South China Sea off Hong Kong: Abstracts 15th INQUA Congress, Durban, pp. 201.

Yim, W.W.-S. and Tovey, N.K. 1995. Desiccation of inner continental shelf sediments during Quaternary low sea-level stands: Geoscientist, v. 5/4, pp. 34-35.

Wyss Yim is an Associate Professor of the Department of Earth Sciences, the University of Hong Kong, Coleader of IGCP 396, and, the Leader of the Contiental Shelf Working Group, Commission on Global Carbon, International Union for Quaternary Research from 1999 to 2003. He was awarded the D.Sc. degree in 1997 by the University of London for published work in the field of applied sedimentology.

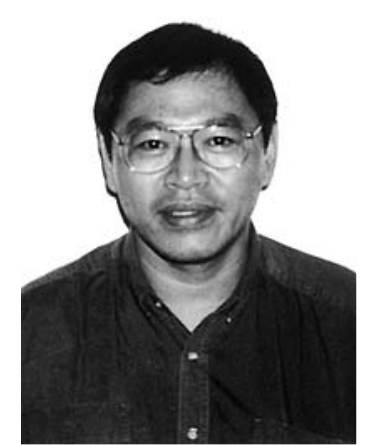

